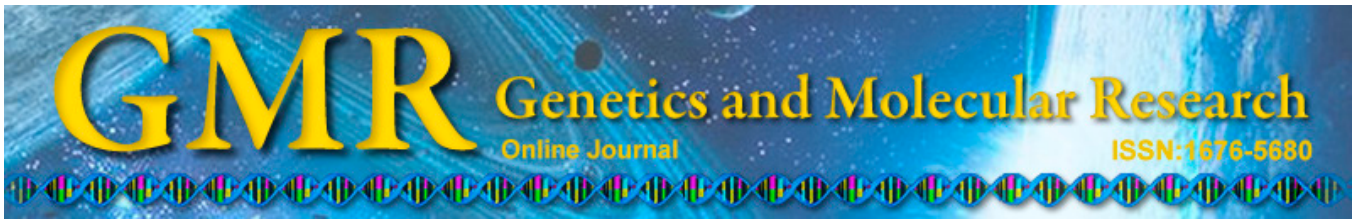

\title{
Biogeographic pattern of genetic diversity detected by RAPD and ISSR analysis in Gypsophila (Caryophyllaceae) species from Turkey
}

\author{
M. Korkmaz and N.Y. Dogan \\ Department of Biology, Faculty of Science and Arts, Erzincan University, \\ Erzincan, Turkey \\ Corresponding author: N.Y. Dogan \\ E-mail: nyildirim@erzincan.edu.tr
}

Genet. Mol. Res. 14 (3): 8829-8838 (2015)

Received November 17, 2014

Accepted March 18, 2015

Published August 3, 2015

DOI http://dx.doi.org/10.4238/2015.August.3.6

\begin{abstract}
Gypsophila L. is the 3rd-largest genus of Caryophyllaceae in Turkey, a country that includes 60 taxa belonging to 56 species of the 126 recognized in the genus. A total of 35 taxa are endemic to Turkey, with an approximately $60 \%$ endemism ratio. In this study, the genetic diversity of 14 Gypsophila species from Turkey was analyzed using random amplification of polymorphic DNA (RAPD) and inter-simple sequence repeat (ISSR) markers. Sixteen RAPD and 6 ISSR primers produced 132 polymorphic bands. RAPD, ISSR, and RAPD + ISSR primers for the 14 species showed 92.7, 93.8, and 92.9\% polymorphism, respectively. Our results indicate that RAPD and ISSR markers are reliable and effective for assessing the genetic diversity of Gypsophila species. Gypsophila species studied were separated into 2 clusters. Our analysis shows that the clusters correlated with geographic and phytogeographic regions.
\end{abstract}

Key words: Gypsophila; Random amplification of polymorphic DNA; Genetic diversity; ISSR 


\section{INTRODUCTION}

The genus Gypsophila L. is mainly an Eurasian taxon that is present in the northern temperate region of the Old World from the Atlantic to the Pacific, and is mainly found between the latitudes of $30^{\circ}$ and $60^{\circ}$. Gypsophila is a typical steppe element, and more than a half of the species in this region have a very limited geographic distribution. The Gypsophila genus originated in Caucasus, the Transcaucasian region, and the Eastern part of Turkey (Barkoudah, 1962). A total of 126 species in this genus can be found worldwide (Koyuncu et al., 2008; Korkmaz and Özçelik, 2011a). Gypsophila L. is the 3rd-largest genus of the Caryophyllaceae family in Turkey. Sixty taxa belonging to 56 species grow naturally in Turkey. Thirty-five of these are endemic to Turkey, with an endemism ratio of approximately $60 \%$ (Korkmaz and Özçelik, 2011a). The members of the genus are commonly known as "Coven" throughout the world ("Çöven" in Turkey), and they are very economically valuable. The plant roots are used for different purposes because of their rich saponin content. The extract produced from their roots can be used as a fire extinguisher, gold polisher, cleaner, and softener of delicate fabrics, as well as give crispness to halva. Turkey is known as the center of diversity of Gypsophila species, and they are indicators of gypsum areas. These species have a large geographical distribution from 100 to 2800 m altitude in Turkey (Korkmaz and Özçelik, 2011b; Korkmaz et al., 2012). Previous studies (Greenberg and Donoghue, 2011; Martínez-Nieto et al., 2013; Pirani et al., 2014) showed that most Gypsophila species form a clade, and the genus appears to be nonmonophyletic. This genus is very interesting from a biogeographic perspective. Although the most Gypsophila species are members of the Irano-Turanian elements, the distribution of the species include temperate Eurasia, the Mediterranean, and the Irano-Turanian regions. Thus, they are ideal models for studying both the effects of habitat fragmentation and selection based on genetic diversity.

DNA-based markers have gained attention because they are unaffected by the environment, detectable at all stages of development, and ubiquitous in number, covering the entire genome. These markers provide a large amount of information; they are highly polymorphic and analytically simple. Therefore, they have played an increasingly important role in the identification and measurement of genetic diversity of different plants (Ercisli et al., 2007). Random amplification of polymorphic DNA (RAPD) and inter-simple sequence repeats (ISSRs) have been used to identify genetic variations between plant species because their applications does not require prior information regarding the target sequence in the genome (Khanuja et al., 1998) and require very little starting DNA template (Zietkiewicz et al., 1994). Thus, this technology has been widely used to investigate the genetic diversity and genetic structure of plant species (Singh et al., 2007; Liu et al., 2008; Ding et al., 2009; Ercisli et al., 2009). There have been no reports examining the genetic diversity of Gypsophila species. Thus, in the present study, we evaluated the genetic variability among the Gypsophila species growing in different phytogeographic regions in Turkey.

\section{MATERIAL AND METHODS}

\section{Plant materials}

The leaf samples of 14 Gypsophila species from Turkey were analyzed in this study. The species examined are G. germanicopolitana Hub.-Mor., G. glomerata Pall. ex Adams, G. heteropoda Freyn \& Sint. subsp minutiflora Barkoudah, G. hispida Boiss., G. lepidioides 
Boiss., G. leucochlaena Hub.-Mor., G. muralis L., G. oblanceolata Barkoudah, G. perfoliata L. var. perfoliata, G. pilosa Hudson, G. pilulifera Boiss. \& Heldr., G. pinifolia Boiss. \& Hausskn, G. tuberculosa Hub.-Mor., G. venusta Fenzl. The analyzed plant samples, including 10 representatives of the Irano-Turanian elements, 2 of the Euro-Siberian, and 1 of the Mediterranean Endemism, phytogeographic regions, and numbers and localities of the Gypsophila taxa analyzed are shown in Table 1.

Table 1. Taxonomic information of Gypsophila species studied.

\begin{tabular}{|c|c|c|c|c|}
\hline Taxon name & Phyto-geographic region & Endemism & Record No. & Locality \\
\hline G. germanicopolitana & Ir.-Tur. & + & Korkmaz: 1689 & Eskişehir \\
\hline G. glomerata & Eu.-Sib. & - & Korkmaz:1971 & Edirne \\
\hline G. heteropoda subsp minutiflora & Ir.-Tur. & + & Korkmaz:1822 & Sivas \\
\hline G. hispida & Ir.-Tur. & - & Kandemir:7037 & Erzincan \\
\hline G. lepidioides & Ir.-Tur. & + & Korkmaz:1937 & Erzincan \\
\hline G. leucochlaena & Ir.-Tur. & + & Korkmaz:1967 & Kütahya \\
\hline G. muralis & Eu.-Sib. & - & Korkmaz:1454 & Tekirdağ \\
\hline G. oblanceolata & Ir.-Tur. & + & Korkmaz: 1881 & Niğde \\
\hline G. perfoliata var. perfoliata & - & - & Korkmaz: 1640 & Sivas \\
\hline G. pilosa & Ir.-Tur. & - & Korkmaz: 1653 & Sivas \\
\hline G. pilulifera & Medit. & + & Korkmaz: 1831 & Kütahya \\
\hline G. pinifolia & Ir.-Tur. & + & Korkmaz: 1952 & Malatya \\
\hline G. tuberculosa & Ir--Tur. & + & Korkmaz: 1928 & Erzincan \\
\hline G. venusta & Ir--Tur. & - & Korkmaz: 1855 & Konya \\
\hline
\end{tabular}

All plant materials were collected from different parts of Turkey (Figure 1). Plant samples were collected from different localities representing the species. After herbarium studies, scientific names of the plant samples were identified according to Davis (1967), Davis et al. (1988), Güner et al. (2000), and Güner (2012). In addition to determining the taxon names, their phytogeographic regions and the endemic taxa were also determined. Most taxa were Irano-Turanian elements. The number of the endemic taxa was $8(57 \%)$. Herbarium samples from each taxa were deposited in the Erzincan University Herbarium.

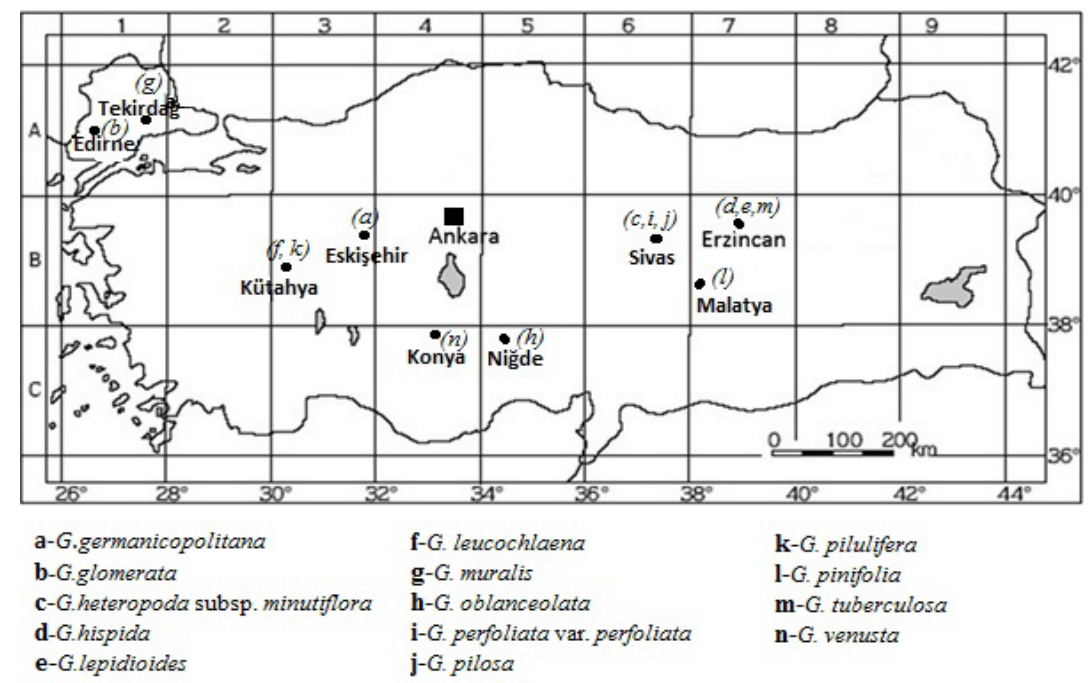

Figure 1. Geographic distribution of studied Gypsophila species. 


\section{DNA extraction}

Genomic DNA was extracted from powdered plant materials using the method described by Li and Quiros (2001). Approximately $1 \mathrm{~g}$ tissue samples were ground to a fine powder in liquid nitrogen in 2-mL Eppendorf tubes. Next, 1 mL DNA extraction buffer (100 mMTris-HCl, pH 8.0, $50 \mathrm{mM}$ EDTA, pH 8.0, $500 \mathrm{mMNaCl}, 20 \%$ sodium dodecyl sulfate, and $10 \mathrm{mM}$ 2-mercaptoethanol) was added and mixed well. The mixture was incubated at $65^{\circ} \mathrm{C}$ in a water bath for 45 min with intermittent shaking at 5-min intervals. The mixture was centrifuged at 12,000 $\mathrm{g}$ for $15 \mathrm{~min}$ at $4^{\circ} \mathrm{C}$ and the supernatant was transferred into a new $1.5-\mathrm{mL}$ tube. An equal volume of phenol: chloroform: isoamyl alcohol (25:24:1) was added and mixed gently. The DNA was precipitated adding 0.6 volume freezer-cold isopropanol and incubated at $-20^{\circ} \mathrm{C}$ for $10 \mathrm{~min}$. The upper phase was discarded after centrifugation for $10 \mathrm{~min}$ at $12,000 \mathrm{~g}$ and $-4^{\circ} \mathrm{C}$. The pellet was washed with $70 \%$ ethanol. The dried DNA was exposed to dry air before being dissolved in $100 \mu \mathrm{L}$ TE buffer.

\section{RAPD analysis}

Samples were screened for RAPD variation using the standard 58-base primers supplied by Eurofins MWG Operon, LLC (Huntsville, AL, USA). The samples were screened for RAPD variations using the standard 10-base primers supplied by Eurofins MWG Operon. A $30-\mu \mathrm{L}$ reaction cocktail was prepared as follows: $3 \mu \mathrm{L} 10 \mathrm{X}$ polymerase chain reaction (PCR) buffer, $1.8 \mu \mathrm{L} 10 \mathrm{mg} / \mathrm{mL}$ bovine serum albumin, $1.2 \mu \mathrm{L} 10 \mathrm{mM}$ dNTPs, $1.2 \mu \mathrm{L} 25 \mathrm{mM} \mathrm{MgCl}$, $3 \mu \mathrm{L} 100 \mathrm{ng} / \mu \mathrm{L}$ DNA, $1.2 \mu \mathrm{L} 5 \mu \mathrm{M}$ primer, $0.4 \mu \mathrm{L} 5 \mathrm{U} / \mu \mathrm{L}$ Taq DNA polymerase (D6677; Sigma, St. Louis, MO, USA), and $17.4 \mu \mathrm{L}$ water.

\section{ISSR analysis}

Twenty-five ISSR primers were screened and 6 primers were selected for further analysis. PCRs were carried out using a single primer in individual reaction in a $25-\mu \mathrm{L}$ volume containing $25 \mathrm{ng}$ genomic DNA, $0.1 \mathrm{mM}$ dNTPs, $2.5 \mathrm{mM} \mathrm{MgCI}$, $1 \mathrm{U}$ Taq DNA polymerase, $1 \mathrm{X}$ Taq buffer, and $0.5 \mu \mathrm{M}$ primer. Amplification was performed using a thermal cycler programmed for an initial denaturation step of $5 \mathrm{~min}$ at $94^{\circ} \mathrm{C}$, followed by 35 cycles of $45 \mathrm{~s}$ at $94^{\circ} \mathrm{C}, 1 \mathrm{~min}$ at the specific annealing temperature, and $1 \mathrm{~min}$ at $72^{\circ} \mathrm{C}$, with a final extension step for $7 \mathrm{~min}$ at $72^{\circ} \mathrm{C}$.

\section{Electrophoresis}

Next, $27 \mu \mathrm{L}$ PCR products were mixed with $3 \mu \mathrm{L} 6 \mathrm{X}$ gel loading buffer and separated by $1.5 \%(\mathrm{w} / \mathrm{v})$ agarose gel electrophoresis in $0.5 \mathrm{X}$ Tris-borate-EDTA buffer at $70 \mathrm{~V}$ for 150 min. The gel was stained in ethidium bromide solution containing $2 \mu \mathrm{L}$ ethidium bromide and $100 \mathrm{~mL} 1 \mathrm{X}$ Tris-borate-EDTA buffer for $40 \mathrm{~min}$ and visualized under UV light in a Bio Doc Image Analysis System with Uvisoft analysis package (Cambridge, UK).

\section{Data analysis}

PCR products were scored as the presence (1) and absence (0) of a band for each species and the data were then analyzed. The data were used to calculate a Jaccard (1908) similarity index, from which an unweighted pair group method with arithmetic mean dendrogram 
was constructed. Dendrograms were produced according to the unweighted pair group mean arithmetic method using the NTSYS-pc ver. 2.02 software (Rohlf, 1998). All experiments in this study were repeated twice. For every primer, 2 PCRs were performed.

\section{RESULTS}

\section{RAPD analysis}

Fifty-eight primers were screened for their ability to generate consistently amplified band patterns, as well as to assess polymorphisms in the species tested. Among these primers, only 16 had generated reproducible and polymorphic bands. The following primers were used: OPC02, B-20, OPD-16, OPBA-03, OPB-10, OPA-01, OPD-20, OPA-13, OPH-10, OPH-16, OPY-15, OPA-17, OPY-7, OPW-1, OPW-8, and OPW-18. A total of 110 bands were recorded and 102 polymorphisms were detected. A total of $92.7 \%$ of the bands were polymorphic. Amplicon sizes ranged from 250 to 3600 . Primers OPY-7 presented the highest number of RAPD products (11). Primers OPB-10 presented the lowest number of RAPD products (3) (Table 2).

\begin{tabular}{|c|c|c|c|c|c|}
\hline Primer & Sequence $\left(5^{\prime}-3^{\prime}\right)$ & Length of amplified bands & No. of bands & No. of polymorphic bands & $\mathrm{P}(\%)$ \\
\hline $\mathrm{OPC} 02$ & GTGAGGCGTC & $300-2100$ & 7 & 6 & 85.7 \\
\hline $\mathrm{B}-20$ & GGACCCTTAC & $500-2700$ & 6 & 6 & 100.0 \\
\hline OPD16 & AGGGCGTAAG & $750-3200$ & 5 & 5 & 100.0 \\
\hline OPBA-03 & GTGCGAGAAC & $250-3000$ & 8 & 7 & 87.5 \\
\hline OPB-10 & CTGCTGGGAC & $400-1800$ & 3 & 3 & 100.0 \\
\hline OPA-01 & CAGGCCCTTC & $300-3500$ & 10 & 9 & 90.0 \\
\hline OPD20 & ACCCGGTCAC & $250-2800$ & 6 & 6 & 100.0 \\
\hline OPA-13 & CAGCACCCAC & $400-3000$ & 7 & 5 & 71.4 \\
\hline OPH-10 & CCTACGTCAG & $500-2600$ & 8 & 7 & 87.5 \\
\hline OPH-16 & TCTCAGCTGG & $600-3400$ & 4 & 4 & 100.0 \\
\hline OPY-15 & AGTCGCCCTT & $500-2800$ & 9 & 8 & 88.8 \\
\hline OPA-17 & GACCGCTTGT & $300-2700$ & 8 & 8 & 100.0 \\
\hline OPY-7 & AGAGCCGTCA & $750-2100$ & 11 & 10 & 90.9 \\
\hline OPW-1 & CTCAGTGTCC & $500-2800$ & 6 & 6 & 100.0 \\
\hline OPW-8 & GACTGCCTCT & $800-3600$ & 4 & 4 & 100.0 \\
\hline OPW-18 & TTCAGGGCAC & $250-2750$ & 8 & 8 & 100.0 \\
\hline Total & & $250-3600$ & 110 & 102 & 92.7 \\
\hline
\end{tabular}

A dendrogram was constructed according to the RAPD data from 14 Gypsophila species, which divided the species into 2 main clusters (Figure 2). The first cluster included $G$. glomerata and G. muralis. The second cluster, which included the largest number of species (12 species), was also divided into 2 sub-clusters: the first sub-cluster included G. pinifolia, G. tuberculosa, G. lepidioides, G. pilosa, G. perfoliata, G. heteropoda, G. leucochlaena, G. hispida, and G. venusta. The second sub-cluster included the species G. oblanceolata, G. pilulifera, and G. germanicopolitana (Figure 2). The greatest similarity was observed between the species G. pinifolia and G. tuberculosa (0.184), and the greatest dissimilarity was observed between the species G. muralis and G. pinifolia $(0.931)$.

\section{ISSR analysis}

We surveyed 14 Gypsophila species using 6 ISSR primers. A total of 32 bands were 
amplified with 6 primers, and 30 bands were polymorphic. The percentage of polymorphic bands produced by each primer ranged from 80 to $100 \%$. A total of $93.8 \%$ of bands were polymorphic. The primer UBC-827 showed the highest number of ISSR bands (8), while the UBC-818 and UBC-848 primers showed the lowest number of bands (4). In general, the size of amplified DNA fragments scores ranged from 250 to $2800 \mathrm{bp}$ (Table 3).

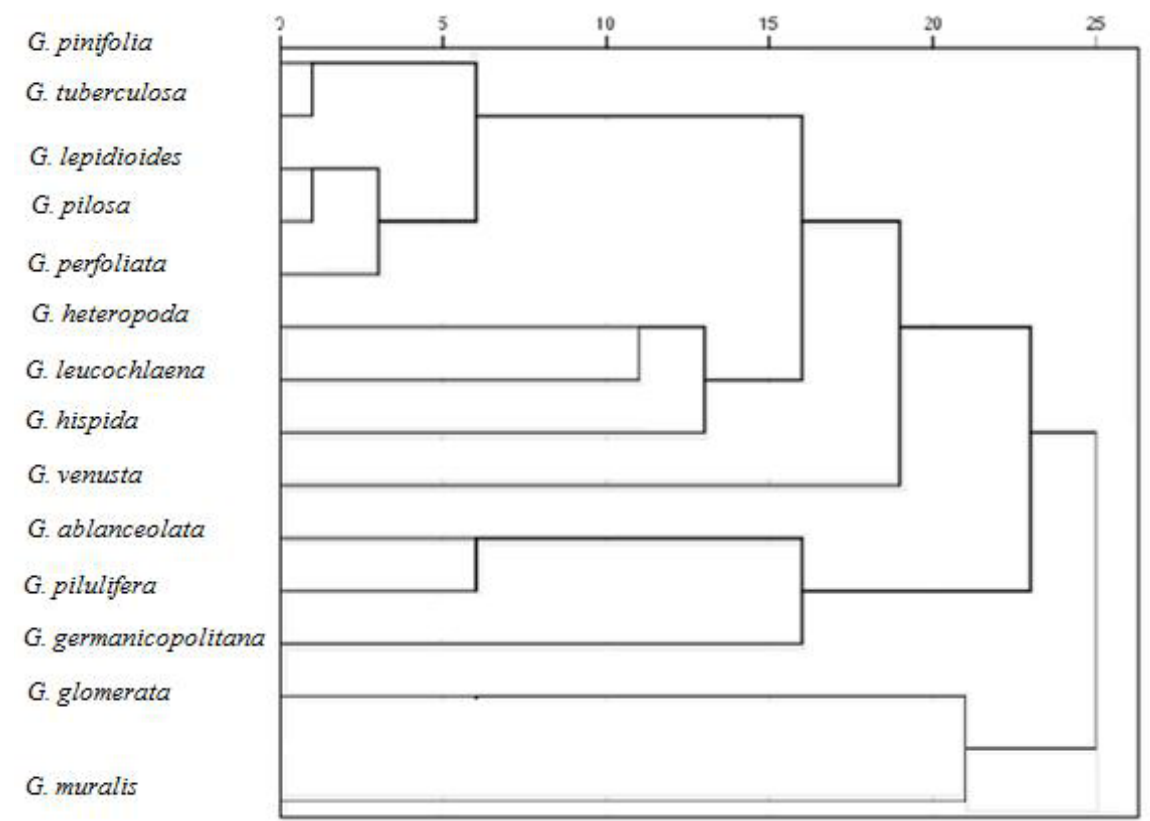

Figure 2. Dendrogram showing the clustering pattern among 14 samples of Gypsophila species as revealed by RAPD markers.

Table 3. Details of banding pattern revealed by ISSR primers.

\begin{tabular}{|c|c|c|c|c|c|}
\hline Primer combination & Sequence $\left(5^{\prime}-3^{\prime}\right)$ & Length of amplified bands & No. of bands & No. of polymorphic bands & $\mathrm{P}(\%)$ \\
\hline UBC-808 & AGAGAGAGAGAGAGAGC & $300-900$ & 5 & 4 & 80.0 \\
\hline UBC-811 & GAGAGAGAGAGAGAGAC & $250-1600$ & 6 & 6 & 100.0 \\
\hline UBC-818 & CACACACACACACACAG & $500-1400$ & 4 & 4 & 100.0 \\
\hline UBC-825 & ACACACACACACACACT & $250-1800$ & 5 & 5 & 100.0 \\
\hline UBC-827 & ACACACACACACACACG & $300-2800$ & 8 & 7 & 87.5 \\
\hline UBC-848 & CACACACACACACACACG & $300-1700$ & 4 & 4 & 100.0 \\
\hline Total & & $250-2800$ & 32 & 30 & 93.8 \\
\hline
\end{tabular}

Cluster analysis revealed 2 major clusters similar to that detected in the RAPD analysis (Figure 3). G. glomerata, G. muralis, and G. germanicopolitana formed the 1st cluster, while the other cluster included 11 species. The other cluster was resolved into 2 sub-groups: the 1st subgroup included G. venusta, G. pilulifera, G. oblanceolata, G. heteropoda, G. perfoliata, G. leucochlaena, and G. hispida, and while the other included G. tuberculosa, G. pilosa, G. lepidioides, and G. pinifolia. The genetic distance based on ISSR data ranged from 0.145 (G. muralis vs G. glomaretaglomerata) to 0.907 (G. muralis vs G. tuberculosa). 


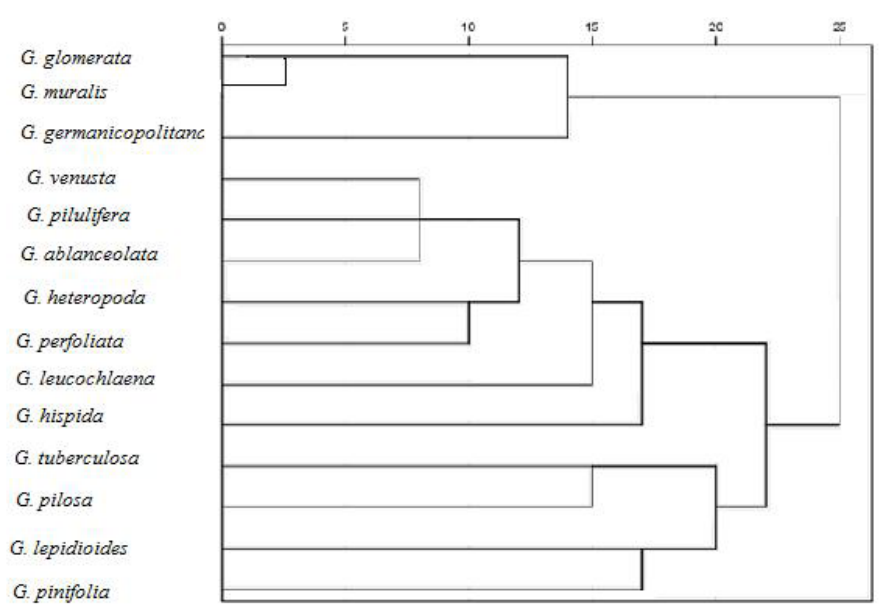

Figure 3. Dendrogram showing the clustering pattern among 14 samples of Gypsophila species as revealed by ISSR markers.

\section{Combined RAPD and ISSR analysis}

Two different types of markers were employed to assess genetic diversity among 14 Gypsophila species. The combined data generated from RAPD and ISSR marker analyses provided 142 bands, 132 bands of which $(92.9 \%)$ were polymorphic, and a dendrogram was constructed (Figure 3). Fourteen Gypsophila species were separated into two 2 distinct clusters, each with containing two 2 species. The 1st cluster included G. muralis and G. glomareta. The 2nd cluster was further separated into 2 sub-clusters with 12 species. The 1 st sub-cluster included G. lepidioides, G. pinifolia, G. tuberculosa, G. perfoliata, G. heteropoda, G. pilosa, G. leucochlaena, G. oblanceolata, G. hispida, and G. venusta, and while the 2 nd sub-cluster included G. pilulifera and G. germanicopolitana. The combined analysis revealed that the similarities of the species ranged from 0.168 (G. pinifolia and G. lepidioides) to 0.892 ( $G$. pinifolia and G. lepidioides).

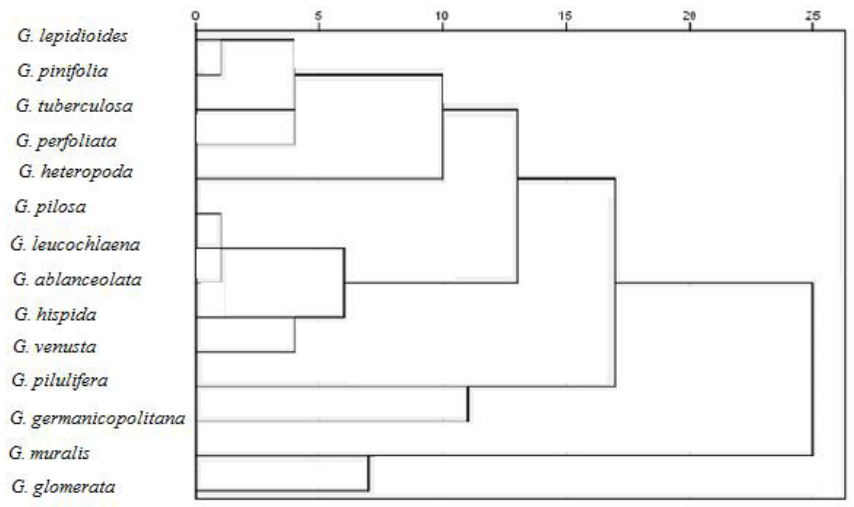

Figure 4. Dendrogram showing the clustering pattern among 14 samples of Gypsophila species as revealed by RAPD and ISSR markers. 


\section{DISCUSSION}

RAPD and ISSR molecular markers have been used to study plant genetic diversity (Liu et al., 2008; Xinjuan et al., 2009; Ramírez et al., 2014). We used PCR-based DNA molecular markers of RAPD and ISSR to analyze the genetic diversity in 14 Gypsophila species. The level of polymorphism of ISSR (93.8\%) in the Gypsophila species was higher than that detected in the RAPD analysis $(92.7 \%)$. Similar results were reported for turmeric (Singh et al., 2012) and Turkish apricot (Yilmaz et al., 2012), with polymorphism levels of 95.4 and $88 \%$ for ISSR and 91.4 and $77 \%$ for RAPD, respectively. Other studies have shown that the ISSR marker is a more efficient marker system than the RAPD marker (Goulão and Oliveira, 2001; Fernández et al., 2002; Behera et al., 2008). In previous studies, ISSR markers were used to determine genetic relationships in the Caryophyllaceae family, such as in Dianthus (Fu et al., 2008) and Silene vulgaris (Egea-Gilabert et al., 2013). Ferrão et al. (2013) reported that the efficiency of a molecular marker indicated a balance between the level of polymorphism and its capacity to identify multiple polymorphisms. Therefore, the ISSR marker is a more efficient technique because of its capacity to reveal a relatively larger number of polymorphisms.

The efficiency of a molecular marker technique depends upon the number of polymorphisms, with greater polymorphism levels indicating greater genetic diversity. RAPD and ISSR molecular markers showed polymorphism levels of greater than $90 \%$. These results indicate high genetic diversity among different species of Gypsophila.

Based on the combined data obtained from RAPD and ISSR marker analyses, 14 Gypsophila species were separated into 2 major clusters. The genetic distance of G. glomerata and G. muralis with other species correlated with their different phytogeographic regions, as they are Euro-Siberian elements. G. pilulifera is only Mediterranean element of the species studied. Dendrogram analysis based upon different marker systems revealed a relationship between the geographical and phytogeographic distribution of the species. The species originating from similar phytogeographic regions, such as G. glomerata and G. muralis, were clustered in the same group. Similar results were previously reported for Curcuma (Islam, 2004), Vicia amoena (Liu et al., 2013), Lilium (Lihua et al., 2014), and Dioscorea (Ramírez et al., 2014) in studies that described the similarity between genetic relationships and geographic distribution using RAPD and ISSR marker analyses.

Two taxa (G. glomerata and G. muralis) were Euro-Siberian elements, and only 1 species (G. pilulifera) was a Mediterranean element. The region of G. perfoliata var. perfoliata is unknown because of its wide geographic distribution. Species originating from the same phytogeographic regions were clustered in the same group (G. glomerata and G. muralis). This may have been observed because of the wide range of ecological and climatic conditions. In this study, we found that RAPD and ISSR markers were powerful tools for fingerprinting and examining the genetic diversity of Gypsophila species and that ISSR markers were more informative than RAPD markers.

\section{ACKNOWLEDGMENTS}

Some plant samples of this study were collected during the project studies numbered as TUBITAK HD 105T299, TUBITAK 105T147, and EUBAP-2011-10.01.05. We are very thankful for the support provided by the institutions. We also thank our colleague Dr. Ali 
Kandemir for collecting plant samples of G. hispida.

\section{REFERENCES}

Barkoudah YI (1962). A revision of Gypsophila, Balanthus, Ankyropetalum and Phyrna. Wentia 9: 1-203.

Behera TK, Singhb AK and Staub JE (2008). Comparative analysis of genetic diversity in Indian bitter gourd (Momordica charantia L.) using RAPD and ISSR markers for developing crop improvement strategies. Sci. Hortic. 115: 209-217.

Davis PH (1967). Flora of Turkey and the East Aegion Islands. Vol. 2. Edinburg University Press, Edinburg.

Davis PH, Mil RR and Tan K (1988). Flora of Turkey and the East Aegean Islands. Vol. 10 (Supplement I), Edinburgh University Press, Edinburgh.

Ding G, Li X, Ding X and Qian L (2009). Genetic diversity across natural populations of Dendrobium officinale, the endangered medicinal herb endemic to China, revealed by ISSR and RAPD markers. Genetika 45: 375-382.

Egea-Gilabert, C, Niñirola D, Conesa E, Candela ME, et al. (2013). Agronomical use as baby leaf salad of Silene vulgaris based on morphological, biochemical and molecular traits. Sci. Hortic. 152: 36-43.

Ercisli S, Agar G, Orhan E and Yildirim N (2007). Interspecific variability of RAPD and fatty acid composition of some pomegranate cultivars (Punica granatum L.) growing in Southern Anatolia Region in Turkey. Biochem. Syst. Ecol.35: 764-769.

Ercisli S, Agar G, Yildirim N, Esitken A, et al. (2009). Identification of apricot cultivars in Turkey (Prunus armeniaca L.) using RAPD markers. Rom. Biotechnol. Lett. 14: 4582-4588.

Fernández ME, Figueiras AM and Benito C (2002). The use of ISSR and RAPD markers for detecting DNA polymorphism, genotype identification and genetic diversity among barley cultivars with known origin. Theor. Appl. Genet. 104: 845-851.

Ferrão LFV, Caixeta ET, Souza FF, Zambolim EM, et al. (2013). Comparative study of different molecular markers for classifying and establishing genetic relationships in Coffea canephora. Plant Syst. Evol. 299: 225-238.

Fu X, Ning G, Gao L and Bao M (2008). Genetic diversity of Dianthus accessions as assessed using two molecular marker systems (SRAPs and ISSRs) and morphological traits. Sci. Hortic. 117: 263-270.

Goulão L and Oliveira CM (2001). Molecular characterisation of cultivars of apple (Malus domestica Borkh.) using microsatellite (SSR and ISSR) markers. Euphytica 122: 81-89.

Greenberg AK and Donoghue MJ (2011). Molecular systematics and character evolution in Caryophyllaceae. Taxon 60: $1637-1652$.

Güner A (2012). A check list of the flora of Turkey (vascular plants). Flora Dizisi 1. NezahatGökyiğit Botanical Garden Publications, İstanbul.

Güner A, Özhatay N, Ekim T and Başer KHC (2000). Flora of Turkey and the East Aegean Islands. Vol. 11 (Supplement II). Edinburgh University Press, Edinburgh.

Islam A (2004). Genetic diversity of the genus Curcuma in Bangladesh and further biotechnological approaches for in vitro regeneration and long-term conservation of C. longa germplasm. Doctoral thesis, University of Hannover, Hannover.

Jaccard P (1908). Nouvelles recherches sur la distribution florale. Bull. Soc. Vaudoise Sci. Nat. 44: 223-270.

Khanuja SPS, Shasany AK, Daroker MP and Kumar S (1998). DNA fingerprinting of plant genetic resources: the need of time. J. Med. Arom. Plant Sci. 20: 348-351

Korkmaz M and Özçelik H (2011a). Systematical and morphological characteristics of annual Gypsophila L. (Caryophyllaceae) taxa of Turkey. Biol. Div. Cons. 4: 79-98.

Korkmaz M and Özçelik H (2011b). Economic importance of Gypsophila L., Ankyropetalum Fenzl and Saponaria L. (Caryophyllaceae) taxa of Turkey. Afr. J. Biotechnol. 10: 9533-9541.

Korkmaz M, Özçelik H and İlhan V (2012). Türkiye'ninbazı Gypsophila L. (Caryophyllaceae) taksonlarınınhabitat özellikleri. BBAD 5: 111-125.

Koyuncu M, Kılıç CS and Güvenç A (2008). Soaprootyielding plants of East Anatolia and their potential in nature.Turk. J. Bot. 32: 489-494.

Li G and Quiros CF (2001). Sequence-related amplified polymorphism (SRAP), a new marker system based on a simple PCR reaction: Its application to mapping and gene tagging in Brassica. Theor. Appl. Genet. 103: 455-461.

Lihua Z, Huamin L, Guangze C and Mingzhong X (2014). Assessment of the genetic diversity and genetic relationships of Lilium in China using ISSR markers. Biochem. Syst. Ecol. 55: 184-189.

Liu C, Ge Y, Wang DJ, Li X, et al. (2013). Morphological and molecular diversity in a germplasm collection of seed pumpkin. Sci. Hortic. 154: 8-16.

Liu LW, Zhao LP, Gong YQ, Wang MX, et al. (2008). DNA fingerprinting and genetic diversity analysis of late-bolting 
radish cultivars with RAPD, ISSR and SRAP markers. Sci. Hortic. 116: 240-247.

Liu Y, Zhang J, Wang X, Liu F, et al. (2013). Genetic diversity in Vicia amoena (Fabaceae) germplasm resource in China using SRAP and ISSR markers. Biochem. Syst. Ecol. 51: 86-93.

Martinez-Nieto MI, Segarra-Moragues JG, Merlo E, Martinez-Hernandez FM, et al. (2013). Genetic diversity, genetic structure and phylogeography of the Iberian endemic Gypsophila struthium (Caryophyllaceae) as revealed by AFLP and plastid DNA sequences: connecting habitat fragmentation and diversification. Bot. J. Linn. Soc. 173: 654-675.

Pirani A, Zarre S, Pfeil BE, Bertrand YJK, et al. (2014). Molecular phylogeny of Acanthophyllum (Caryophyllaceae: Caryophylleae), with emphasis on infrageneric classification. Taxon 63: 592-607.

Ramírez APV, Morána MIT, Moret SM, González JJS, et al. (2014). Efficiency of RAPD, ISSR, AFLP and ISTR markers for the detection of polymorphisms and genetic relationships in camote de cerro (Dioscorea spp.). Elect. J. Biotechnol. 17: 65-71.

Rohlf FJ (1998). NTSYSpc: Numerical taxonomy and multivariate analysis system version 2.02. Exeter Software, Setauket.

Singh AK, Behera TK, Chandel D, Sharma P, et al. (2007). Assessing genetic relationships among bitter gourd (Momordica charantia L.) accessions using inter simple sequence repeat (ISSR) markers. J. Hortic. Sci. Biotechnol. 82: 217-222.

Singh S, Panda MK and Nayak S (2012). Evaluation of genetic diversity in turmeric (Curcuma longa L.) using RAPD and ISSR markers. Indust. Crop Prod. 37: 284-291.

Yilmaz KU, Paydas-Karg1 S, Dogan Y and Kafkas S (2012). Genetic diversity analysis based on ISSR, RAPDand SSR among Turkısh apricot germplasms in Iran Caucasianeco-geographical group. Sci. Hortic. 138: 138-143.

Xinjuan L, Liwang L, Yiqin G, Liping Z, et al. (2009). Cultivar identification and genetic diversity analysis of broccoli and its related species with RAPD and ISSR markers. Sci. Hortic. 122: 645-648.

Zietkiewicz E, Rafalski A and Labuda D (1994). Genome fingerprinting by simple sequence repeat (SSR)-anchored polymerase chain reaction amplification. Genomica 20: 176-183. 